\title{
What Really is the American Dream?
}

Author: Alexander Bruno

\begin{abstract}
This paper takes a closer look at the Constitution of the United States of America (USA) and its role in shaping the American aspiration which is generally referred to as the 'American Dream.' The American Dream, therefore, can be seen as the original plot which is played out by Americans in their determination to thrive. Essentially, this paper reviews key contributions by noted scholars with reference to the American Dream. For the purposes of this research, two definitions of the American Dream are proposed; both of which are traced back to the pre-colonial American spirit. The working definitions are: 1. The American Dream is 'an indigenous belief in the unbridled freedom and unique heritage of a people' and 2. The American is 'the belief in self-actualization of the good fortunes, guaranteed by American liberties, opportunities and freedom.' Those definitions are examined in line with the scholarly works which were reviewed for this research. Above all, this paper can be seen as a continuation of the discussion on the American Dream.
\end{abstract}

\section{Introduction}

In search of the unchanging quality in the phenomenon called the American Dream...

The way of life refers to the way things are. To have aspirations of grandeur, especially for unknown ideas is to dream. This is what guides the notion of the American Dream, but the question still remains: what really is the American Dream? This research article attempts to answer the question by analyzing the opinions of scholars on the same topic, and harmonizing those discussions into a synthesis that would best describe the American Dream. To dream is to aspire, and one's aspiration may be seen as their ambition - past, present and future - to achieve that which is achievable, and even to obtain the unattainable. In the context of the American Dream, the peoples' ambition is to obtain the promise of the Declaration of Independence, the nation's Constitution, the Constitutional Bill of Rights and the American creed. Lipset (1996) affirms that the American Constitution intensifies the commitment to individualism and concerns for the 
protection of rights. ${ }^{1}$ The author further establishes that "the American Bill of Rights [is] designed to protect the citizenry against the abuse of power by government,"2 and it is this protection which guarantees and fuels the pursuit of the American Dream.

The core of the July 4, 1776 Declaration of Independence reads: "we hold these truths to be self-evident, that all men are created equal, that they are endowed by their Creator with certain unalienable Rights, that among these are life, liberty and the pursuit of happiness." ${ }^{3}$ The US creed establishes "principles of freedom, equality, justice, and humanity for which American patriots sacrificed their lives and fortunes"4 as core virtues. It is necessary to weave through the ontological sources when making a theoretical argument, especially when attempting to build arguments for such ideas like the American Dream. It is therefore for this reason why my inquiry rummages through those founding documents to fashion a deeper insight on the American Dream. It seems clear that the creed and endowment contained in the emancipation proclamation help to shape the dream. The creed and declaration serve as pivots on which the American Dream spins from past indigenous resilience to more contemporary American aspirations.

\section{Discussion}

It could be strongly argued that the Constitution of the United States of America, the declaration of independence, and the US creed share the same core tenets. From the first three words, We the People, the Constitution promises the dream and identifies citizens as the purveyors of success within the American system. The complete preamble of the U.S. Constitution reads:

We the People of the United States, in Order to form a more perfect Union, establish Justice, insure domestic Tranquility, provide for the common defence,

1. American Exceptionalism, Lipset. 1996. A Double-Edged Sword.

2. American Exceptionalism, Lipset. 1996. A Double-Edged Sword.

3. US History.org, The Declaration of Independence: The Want, Will and Hope of the People.

4. US History.org, Historic Documents: The American Creed. 
promote the general Welfare, and secure the Blessings of Liberty to ourselves and our Posterity, do ordain and establish this Constitution for the United States of America. $^{5}$

The connecting ideas contained in the preamble to the US Constitution and the other founding documents speak to principles of freedom, fortunes, equality, rights, life, justice, liberty, welfare, and posterity. These are elements of the American Dream which can only be defined by the individual citizen, based on their ambition and the enabling environment which drive such ambition. In that case, the American Dream is not necessarily or solely a standard ideal, but it varies from one person to another.

Enabling environment here means the right opportunities and a set of foundational qualities, over time, which lend to human flourishing. This is so because, freedom, fortune, equality, rights, life, justice, liberty, welfare, and posterity can be defined by time and place or context in history, those qualities may take on different representation(s) to people overtime. African-Americans who were not even regarded as being citizens, years following the time following the Declaration of Independence and the drafting of the Constitution, could not have been said to be part of this all-conquering spirit defined as the US Constitution. Remember, we argue that the Constitution helped to drive the narrative of the American dream - and I believe it still does, although that dream did not exist for all in the same way, all the time.

The aspiration which the Constitution carries makes it possible for those who were not necessarily and immediately covered by the promise called America would be bounded by the elasticity of the articles contained in that Constituting document. The critics of the Constitution are justified, but so too are those who understand the flexibility, ambiguity, contradictions and

5. National Achieves, America's Founding Documents: The Constitution of the United States. 
adaptive nature of this founding document (and the American experiment for that matter), and how open it remains to vast and contrasting interpretations. These prospects assist with the placement of the American Dream in a document that probably did not enunciate any direct promise for a large subset of the American society - such is the nature of an American society which at time is referred to as a major contradiction.

Many, including women, lacked the basic prerequisites necessary for success in early American society. This is important to note, as ideas evolve over time and with the advancement of knowledge, but aspirations such as the American Dream represent the basic structure upon which the foundation of a nation resides. Ideas are mental categories with idealist aims; a theory in contrast, is a system of ideas which seek to explain a separate and independent entity, especially one based on general principles. The American Dream is therefore ruled out as a theory, and we have already observed that it is not always an ideal. So, the question still remains: what really is the American Dream?

If indeed there is an American Dream, there is little doubt that this dream is rooted in the founding articles as has already been discussed. Since the work of theorists generally calculates meanings through several theories, rather than experiences or practices, this essay focuses on identifying a simplified and definitive explanation of the American dream - not necessarily to challenge it. Scholars have discussed the idea of the American dream in a way that satisfactorily identifies the aspiration, but the literature comes up slightly short on a clearly defined working definition or rational. I attempt to address this by first identifying the American Dream within the founding institutions of the United States. Though the idea of the dream exists in indiviuals' aspirations, the very notion of the dream is ideally placed (though it is not a standard or collective ideal), and sometimes it is said or thought to be practical and attainable. This means that the dream 
may take on several forms. It is my view that the American Dream can indeed be firmly grounded - base on the existing scholarship, and granted academic credential. By this I mean, there could be a clearer scholarly path of the placement of that American aspiration; somewhat of a literary weaving of the dream by connecting or synthesizing the ideas from the founding articles of the United States.

Jillson (2016) sees the American Dream as "the broad promise of the American life," and adds that the American Dream "was denied to many Americans for most of the nation's history."” The question is, therefore, when does the dream begin and where does it end? We learn from Jillson (2016) that the dream has been denied, and this is one of the factors which drives this research to determining how an aspirational ideal could be denied. Remember, however, that it was earlier noticed that the dream could also be 'attained' or 'achieved,' so if the ream can at times be attained; it can at times be denied. Maybe Jillson (2016) is unto something here, but the scholar is still vague. The question, then, is not whether the dream exists, but how it exists. It would appear also that the dream assumes different practical senses and forms, and though this may be the case, a standard construct would probably better serve the dream.

What appears to be certain is that the overarching concept of the American Dream is not planted in material accumulation, although - especially in more contemporary era - the dream generally finds itself manifested in material or capital gains and/or achievements. If one were to examine the idea of the dream as material accumulation, there is little doubt that this also constitutes the dream, but is this all that dreamers aspire for? If the answer is no, and it is very likely that it is - no, we know that the American Dream is not restricted to an accumulation of money, a house, car, boat, bling-n-thing (the niceties which drive humanity) and other material

6 . The American Dream, Jillson, 2016, 1, In History, Politics, and Fiction.

7 . The American Dream, Jillson, 2016, 1, In History, Politics, and Fiction.

Bruno, 2019. What Really is the American Dream? 5 
possession(s) or fetish. For some, the dream is to set foot on the US shores, to earn a livelihood and to be able to care for their families; others simply dream to earn a decent education. The dream, for some, may be fame and recognition and life in the fast lane, and for others only dream might be to die doing whatever pleases them. The way it appears is that, no one can truthfully affix their version of the American Dream on anyone else.

Jillson (2016) observes that "the past disappointments and defects, the rising inequality, the declining mobility, and the shrinking middle class have left many convinced that the American dream is no more," ${ }^{8}$ Cullen (2003) shares a similar view. He declares that "you'll never really understand what it means to be an American of any creed, color, or gender if you don't try to imagine the shape of that dream." The author goes on to state that "the American Dream of the Founding Fathers was freedom,"10 and in the same breath, he claims that "in some important respects freedom was not a dream at all but rather a living reality." ${ }^{11}$ It seems, therefore, that the American Dream is an illusionary reality - for some - as there are many things which corrode, impede or challenge the attainment of the American Dream.

The dream is an illusionary aspiration because it is premised on a set of unchangeable and personal ideals with no definite theoretical syntax, but the dream is a reality in that it helps individuals navigate from their own circumstances and gravitate to a place of perceived or inspirational hope. Delbanco (1999), in his writings on the American Dream, agrees that "the struggle to secure this chance for all Americans has been bitter and bloody, and it is far from over." ${ }^{\prime 2}$ The trend here is clear as it suggest that the American Dream is not a structured concept,

8. The American Dream - In History, Politics, and Fiction, Jillson, 2016, 259.

9. The American Dream, Cullen, 2003, 13, A Short History on an idea that Shaped a Nation.

10. The American Dream, Cullen, 2003, 41, A Short History an idea that Shaped a Nation

11. The American Dream, Cullen, 2003, 41, A Short History on an idea that Shaped a Nation.

12. The Real American Dream, Delbanco, 1999, 87. 
although it is the ideal which has shaped America. With that being the case, the American Dream requires the sort of definition which this research shall later suggest, but we must first present a discussion and ratify that definition.

de Crevecoeur (1782) refers to the American Dream as the ethos of freedom and opportunity, ${ }^{13}$ but he, like all other scholars falls short in offering the exact characteristics of that dream - probably the dream is not even supposed to be so characterized. But, this research takes the position that the dream is tied to the indomitable spirit which drives the quest for freedom, fortunes, liberty and welfare in the American person. The dream in itself, however, is not a measurable entity; it is satisfaction of accomplishment and very situational and personal. So, the theoretical framing for the American Dream is: the belief in self-actualization of the good fortunes, guaranteed by American liberties, opportunities and freedoms.

The spirit of newness drives the quest to conquer, so the American Dream is a conscious, as well as a 'spiritual' pursuit of anything that the dreaming believes is possible. To qualify this position, let us again turn to de Crevecoeur (1782) for a deeper insight as he is one of the early proponents of the 'Great Spirit' which drives the American ideal. By going deeper, it is hoped that the search helps to define a synthesized understanding for, and a rightful place of the dream. A more concise understanding of the spirit of the American person is therefore foundational to understanding the dream. What is the basic characteristic or indivisible element of the American person? To answer the questions, this exercise takes on this critical narrowed-down function, aimed at discovering this common notion or claim, that there is indeed something special about being an American. If there is that special something, it has to be the American Dream.

13. Letters From an American Farmer, de Crèvecœur, 1782, 39.

Bruno, 2019. What Really is the American Dream? 7 
The views of de Crèvecoeur (1735 - 1813) help in framing the search, and ad the fuel to the ongoing discussions on the American Dream. As one of the original radicals of American fundamentalism, de Crèvecoeur identifies and articulates the essence of the ideal American person with his appeal to the unknown, and unseen, for blessed guidance for the preservation of the land which he loved. He writes:

I beseech Thee O Father of Nature, that our ancient virtues, and our industry, may not be totally lost: and that as a reward for the great toils we have made on this new land, we may be restored to our ancient tranquility, and enabled to fill it with successive generations, that will constantly thank Thee for the ample assistance Thou has given them. ${ }^{14}$

What the author is saying here is that, the divine 'father' of nature grants unto willing participants, the ability to reach beyond themselves to gain that which s/he may not even be aware of. This is more or less the guiding idea behind the aspirations of the American Dream.

de Crèvecoeur, who contributed this at a time when the essence of the American identity was being conceived, adds that "self-preservation is above all [other] political precepts and rules, and even superior to the dearest opinions of our minds; a reasonable accommodation of ourselves to the various exigencies of the times in which we live."15 Without even knowing the spirit, one knows, or is at least aware that something other than materialism drives human ambitions; even if those ambitions are seemingly satisfied in, or by material manifestations. Self actualization is fundamentally an American ideal because it is promised through the articles of the nation's founding documents. The dream is therefore uniquely America, as there is hardly other such

14. The Norton Anthology, de Crèvecoeur, 625.

15. The Norton Anthology, de Crèvecoeur, 621. 
written or unwritten promise of national construction which ties human livity into its structural framing.

The interpretation of de Crèvecoeur's statement may be seen in other lights, but he is reflecting on the essence of renewal by revisiting the past, and this occurred way before the colonial experience. de Crèvecoeur was of course speaking from a front-row seat in the theatre of divine authority, having experienced the workings of colonialism during his teenage years in England. After de Crèvecoeur settled in New York following a tour of duty with the Canada militia, he found America to be a place of renewal, as was captured in his letters from an American Farmer, quoted in preceding paragraphs.

The dream therefore can be seen as the possibilities of renewal and/or redemption. The expressions of freedom in those early days all seem to echo the same clarion call. There had been (and probably there still is) this prevailing sentiment hovering over the American society in the early contacts with human realities and the challenges of renewal. Sentiments of ownership of one's personhood, and the ability to fend-off further negative encroachments was the modus operandi of the early American narrative (probably it still is). Something was happening with the American citizenry in the founding era, and it was as if it were ordained by the Great Spirits. There were revolutionaries and there were loyalist. Revolutionaries waged aggression against loyalists and this helped in weaving that innate sense of the togetherness spirit; a belief which strengthened the cause of rediscovering America, and reaffirming the aspiration of the American person - not just as individuals, but also in the collective sense.

The English man, Thomas Paine $(1737-1809)$, who is listed as "the most persuasive rhetorician of the case of [American] independence," 16 is one of those individuals who harbored

16. The Norton Anthology, de Crèvecoeur, 639 
the early American personhood. Operating in colonial America during the time of spiritual upheaval, Paine pontificated that "it is necessary to the happiness of man that he be mentally faithful to himself." ${ }^{17}$ It is, therefore, my understanding that there is an essence behind any physical manifestation, and that essence is the spirit. This spirit is that same agency which Paine evoked to savagely attack the insularity within 'civility' in his 'Common Sense: thoughts on the Present State of America narrative.' Paine challenged colonialism head-on. He accreted that "even the distance at which the Almighty hath placed England and America is a strong and natural roof that the authority of one over the other was never the design from heaven,"18 and further suggested that "the name of the ancestors will be remembered by future generations with detestation,"19 should the veil of colonialism be allowed to cover America. Every suggestion in the preceding paragraph speaks to the existence of that special something which is not seen, but which is very present in the American quest to, not just survive, but to thrive.

From the early days of the American awakening, great emphasis was placed on the autonomy of the individual person. The individual was endowed with a sense of invincibility, connected to their unfettered ability to make connection with the ancestors, aided by the forces of nature. This ancestral connection is the spirit of the people, and that spirit is the driving force behind the power of nature. In retrospect, it is this spirit which, according to the early manifestations, which give the American citizen his or her unique personhood and shapes the model nation - America - which is highly touted today. This spirit encapsulates the nature of the American person - it is their dream...the American Dream.

17. The Norton Anthology, de Crèvecoeur, 639

18. The Norton Anthology, de Crèvecoeur, 649

19. The Norton Anthology, de Crèvecoeur, 642 
To state it simply, the idea of the ideal American person stems from the aspirations of the "presence of the Great Spirit," ${ }^{20}$ and that Great Spirit, as has been determined, comes from the combined uniqueness of the original inhabitants in the undisturbed (or some may say ruthless) state of nature. This case is taken forward by Charles A. Beard (1874-1948) who writes that "progress is not inevitable but...is dependent on human will and effort." ${ }^{21}$ What Beards means by this is that there is no defined or guaranteed concept which can be claimed as the spirit. $\mathrm{He}$ suggests, in the predicate of his proposition, that the spirit is a progressive search, and so it is the spirit which grants the American his or her agency and/or citizenship. In fact, when Pontiac speaks of the presence of the 'Great Spirit,' he is actually saying that the spirit is the active search for, and the refinement of citizenship virtues. Embedded in the spirit is also the belief in a mission of completeness, just as Beard expressed. The spirit is a progressive activity, as is discovered in the illustrations of those interesting characters (and scholars) who were engaged in galvanizing awareness during the early American revolutionary era. The spirit is the main building block of the American way - the American Dream, which is anchored in the people's will.

Continuous reference is made to the 'Great Spirit' during and even after the American revolution. In fact, discussion about the spirit has been unceasing through America's history, and my aim is to zoom in on the agency of that spirit of the American ideal. So far we have sought to establish a common refrain: the spirit of the people which is determined by the 'Great Spirit' during the reawakening and how this continues to manifest itself in the life of Americans. The discussion can, therefore, progress with this connection of the present to the past. In fact, the indigenous revolutionary, Red Jackket, provides the linkage from the establishment of the spirit to its

20 . The Norton Anthology, Savage (Pontiac), Old English Libraries: the Making, Collection And Use of Books During the Middle Ages, 444.

21. New Order of the Ages, Lienesch, 1988, Time, the Constitution, and the Making of Modern American Political Thought 
acceptance. In defense of the traditional beliefs of the original American Indians, Sagoyewatha, or 'Red Jackket' as he was generally called, state the following:

Friend and brother; it was the will of the 'Great Spirit' that we should meet together this day. He orders all things, and he has given us a fine day for our council. He has taken his garment from before the sun, and caused it to shine with brightness upon us; our eyes are opened, that we see clearly; our ears are unstopped, that we have been able to hear distinctly the words that you have spoken; for all these favors we thank the Great Spirit and him only. ${ }^{22}$

Red Jacket continues - with his address to the Seneca, an amalgamation of Native Indian communities that pre-dates the United States Constitution, by stating that, "there was a time when our forefathers owned this great land." ${ }^{23}$ Sagoyewatha states further:

Their [the forefathers,] seats extended from the rising to the setting sun. The 'Great Spirit' had made it for the use of Indians. He had created the buffalo, the deer, and other animals for food. He made the bear and the beaver, and their skins served us for clothing. He had scattered them over the country, and taught us how to take them. He had caused the earth to produce corn for bread. All this he had done for his red children because he loved them. ${ }^{24}$

When one takes a microscopic view of Sagoyewatha's statements, it seems clear that he is invoking a certain passionate pride in his audience which does not merely rest upon the surface of his utterances. There is more going on beneath the text, and the mention of the spirit is an indicator of

22. The Norton Anthology, 451.

23 . The Norton Anthology, 451

24 . The Norton Anthology, 451 
that essential quality, or authority, which the individual possesses; the essence to dream; to aspire, to succeed; to achieve.

What Sagoyewatha did not actually say, in my view, is that such spirit is a creation of one's own will and desire to survive, to be respected, to be free and to strive. It is this spirit which is captured in the literary discussion of American luminaries and early patriots like Benjamin Franklyn, Thomas Jefferson and Thomas Paine (whom we have already dealt with in some detail). These individuals had the collective discernment of the spirit of the American person, and they were not shy about their convictions as we shall discover at the conclusion of this essay. In fact, it is only fitting that the culmination of this particular discussion becomes the starting point of another conversation in this synthesis of literary expressions on the spirits of the American person - the American Dream. The American Dream is, therefore, that unbroken spiritual vehicle which propels peoples' aspirations.

From the early days, based on an understanding of the literature, it became clear what America meant to the people and what role they, 'the people, 'would play in that 'new America.' Again, we refer to the spirit, or the dreams and aspirations of the American person. A dream to aspire and to strive; a continuous quest to keep the ambitions of a unique people alive, and it is this very attitude which drives my research and places this discussion in its proper context. The spirit of this new nation, America, would serve as a blueprint to the dream and it is in fact the dream. All future references to 'the spirit' is replaced by 'the dream' or the 'American Dream' for the remainder of the narrative. The dream supports America's renewal. The dream represents a melting pot of ideas, cultures, values and rugged individualism. The dream is contradictions; it is boundless propensity and endless prosperity. The dream is a progressive action, or belief, or faith in those vastly unknown strengths which are enshrined in the American ideal. The dream is a 
pursuit; it is undeniable, transcendent, pure and some say - true. This dream moves the American person into existence among other peoples and nations, and calls her or him into action. This dream is uniquely America, or American, because it dispels the colonial notion of submission.

The discussion has arrived at this stage where a clearer and more concise reasoning of the American Dream may be had. The American Dream is seen as independent from a mediating supreme; it is its own mission which appeals to different individuals in varied ways. The dream shifts the dynamics away from subjected people to free individuals. The American Dream explains what is possible in the land of the dreamers - American. The progressive search for the dream is the dream itself, and that dream is planted in, or evolves from the peoples' aspirations. The people's aspirations is not in the domains of any sort of foreign entity or force, instead, it is a journey towards that which is unknown and that which is possibly bigger than the person. By identifying the dream through the progressive search, the American person is unique and this uniqueness became evident during the early colonial/republic or revolutionary era. The dream is present today and it shall remain so (or it may get even better defined) in the future.

With the three words, 'We the People,' the Constitution places people at the centerpiece of the foundation upon which 'The American Dream' is built. There are those who lose their lives in the pursuit of an elusive 'American Dream' and others who boast of living the dream each and every day. Although there may not be a set definition for the American Dream, there are notions, as has been discussed, which establish the concept of the dream. These are embedded in the articles of the founding documents of the United States of America, and are kept alive through the civil liberties. Del Cid (2011) takes this idea of the American Dream to the contemporary era. She writes 
that "the American Dream is globally acknowledged due to media forms such as television and the internet" 25 in recent times in particular.

The American Dream has become manifested in the Congress of the United States of America. The Dream Act of 2017 which brought legislators on rival sides of Congress together is said to be in support of America's values:

The Dream Act treats young undocumented immigrants brought to the U.S. as children — some as babies — fairly by providing a permanent legislative solution that allows them to stay in the U.S. The bill prevents Dreamers from deportation to a country where they did not grow up and many do not remember. It allows them to reach their full potential and have the opportunity to become American in the eyes of the law, contributing to a brighter future for all Americans. ${ }^{26}$

The principle of the 'Dream Act, (as stated above) is hence clearly documented. The American Dream is, therefore, not entirely elusive, or idealist, and it is certainly not vague. The Congressional Dream Act confirms that the American Dream is what it means for each individual, but it is also an American responsibility to the fulfillment of a collective promise. This promise allows for individuals - in this and future generation - to live out their full potential with the opportunity of becoming an American and to contribute to a brighter future for all Americans.

The dream is personal and it is collective. It certainly ratifies the early American motto: $E$ pluribus unum - 'Out of many, one' "One out of many or 'One from many' which was adopted by an Act of Congress in 1782 and considered the defacto motto of the U.S. until the mid $20^{\text {th }}$ century. ${ }^{27}$ The inscription, E pluribus unum, remains indelibly printed on the Great Seal of the

25 . The American Dream, Del Cid, 2011, 15, An Illusion or Reality for Latino Immigrants

26. National Immigration Forum, Dream Act of 2017 - Bill Summary, Penichet-Paul, 2017.

27. U.S Department of The Treasury - An Official Website of The United States Government: E Pluribus Unum. 
United States today, and it seals the dream of the people - individually and collectively. That indomitable element is the spirit of the emancipation proclamation, the fervor of the constitution and the driving force behind the American Creed; simply put, the dream is the active ingredient in America's founding documents. There is to be no doubt, therefore, that the funding principle of the American nation, especially the emancipation proclamation, has given definition and meaning to the American dream, and that the American way promotes and protects the spirit which drives such dream. It is also true that US Constitution and the other founding documents - especially the Constitutional the Bill of Rights and other Amendments - are living testimony of the Framers' intent.

The dream, in contemporary America, exudes this spirit which is easily experienced and readily shared, but which may not to be arbitrarily framed, especially in the realm of materialism. In other words, the American Dream may not be watered-down to only reflect material gains or overconsumption. The spirit of the American people is the American dream; the American dream is a spiritual understanding of the characteristic of one's American-ness. One's American-ness is their dream of fulfillment, success, satisfaction, achievement, contentment, hopes, liberty, aspiration(s), identity, progress, thriving and conquest. Though the Constitutional Bill of Rights guarantees certain civil liberties, rights and freedom, and showers the blessings of liberty on each individual, with all of this comes responsibility; the responsibility to respect other's rights, liberties, freedoms and blessings of liberty and it is the spirit of the American people or the American dream which sanction's this.

\section{Conclusion}


When one is able to sift through the contradictions, insularities, imperfections and intentions of the experimental model called the United States; s/he will discover the framework of what was intended. This intent or framework, as we have discussed, is the 'spirit' of the American Dream. Seeing that the spirit is a progressive endeavor towards whatever the individual's idea of progress is, it is not perfect nor is the system which sets it up or any other system for that matter. If the American person deviates from his/her honest 'self-beliefs, there will be a contrite knocking against the front door of the awareness mechanism which each person is endowed with; thus, the true spirit is kept alive and may remain alive for an eternity - at least for as long as humanity exists and the need for necessity directs the dream's existence.

The bits and pieces which have been weaved together in this research suggest that the American Dream did not just arrive; it was worked at, and the same became self-evident. The bitter struggles of the earliest settlers guaranteed the sweetness of the dream in the present generation. For some, however, the dream remains bitter. If the dream is to remain true (biter of sweet), the present generation must ensure that it is passed on in its purest form. This American Dream is not laced in political warfare, nor is it maintained by special interests or a particular sector or strata. In fact, when parasitic entities threaten to reframe the dream under a simple and a collective definition, the peoples' rugged individualism will have the last recourse.

The new wave of 'dreamers' has given the American nation a new hope to dream in ways that meets with the reality of the times. One of the more astute American pragmatist, William James $(1842-1910)$ asserts that "the philosophy which is so important in each of us is not a technical matter: it is our more or less dumb sense of what life honestly and deeply means." 28 With this radical retooling of the dream, the road to the future seems clear, and the dream may yet be

28. Pragmatism, James, 1975, 10 
here to stay. America is by no means a perfect nation, but her imperfections serve as a constant reminder that the dream must be worked at and that the people cannot fall asleep at the wheel. The blemishes and imperfections of the American society challenge the people to remain vigilant and to create opportunities for generations to come, so that they too can boast of an American Dream.

The dream is you and how best you relate to the dream. It is a sense of contentment in an enabling environment. The American Dream has even transcended the landmass called America. The several US interventions, not necessarily military, have made sure of that. Cultural exchanges, academic opportunities, the media and other technological advancements are all vehicles of the American Dream, and it would not be surprising if the dream is manifested in faraway lands with the same veracity as occurs on the American homeland. It is incumbent that each individual keeps the dream alive with the checks and balances contained in the Constitution of the United States of America, though this document has had its fair share of interrogation, examination, beliefs and doubts, and - yes - contradictions and contrasting interpretations.

The spirit which was referenced throughout the discussion has been collapsed into the dream. The dream, as had been affirmed, is tied to human pursuits and aspirations. Let us now revisit the two working definition of the American Dream which were advanced by this essay. They are, 'An indigenous belief in the unbridled freedom and unique heritage of a people' and 'The belief in self-actualization of the good fortunes, guaranteed by American liberties, opportunities and freedom.' The discussion throughout this essay leads to a natural progression into both meanings of the American Dream. There may of course be several other justifiable definitions, but I offer these as a means of frames for ongoing discussions. Definitions, in and of themselves, can be problematic because each individual may ascribe their own meaning and understanding to words and definitions. 
It is for the final reason stated previously that the question still remains: what really is the American Dream? Tis question is probably even unanswerable as the American Dream itself, but the effort was made to bring us closer to what I believe is a more concise reasoning. One thing which could be agreed upon is that a search for the unchanging quality in the phenomenon called the American Dream can be limited to the articles of the foundation of the United States, the resolve of its people and the promise of the future. 


\section{Reference}

Constitution of The United States: Charters of Freedom. Retrieved on April 5 3, 2018, from, http://www.archives.gov/exhibits/charters/constitution.html

Goodman, R. 1995. Pragmatism: A Contemporary Reader

Huntington, Samuel, P .1981. American Politics: The Promise of Disharmony. Cambridge: Mass.; Harvard University Press.

Jillson, Cal. 2016. The American Dream, In History, Politics, and Fiction- University Press of Kansas

Leigh, Jessica. 2011. "The American Dream" - An Illusion or Reality for Latino Immigrants" Senior Honors Theses. 244. http://digitalcommons.liberty.edu/honors/244

Lipset, Seymour Martin. 1996. American Exceptionalism: A Double-Edged Sword. New York W.W Norton.

Lienesch, Michael. 1988. New Order of the Ages: Time, the Constitution, and the Making of Modern American Political Thought.

Leigh, Jessica .2011. "The American Dream: An Illusion or Reality for Latino Immigrants" Senior Honors Theses. 244. http://digitalcommons.liberty.edu/honors/244

National Archives. America's Founding Documents. Sourced from https://www.archives.gov/founding-docs/constitution-transcript on April 4, 2018. de Hector (1782) in 'Letters from an American Farmer'(1782)

Penichet-Paul, Christian. 2017. National Immigration Forum, Dream Act of 2017 - Bill Summary. Sourced from https://immigrationforum.org/article/dream-act-2017-bill-summary/ on February $25,2019$.

Savage, Ernest Albert, 1877-1966. Old English Libraries: the Making, Collection And Use of Books During the Middle Ages. London: Methuen \& Co. Ltd, 1912.

The Norton Anthology American Literature, Eight Edition. Baym, N (General Editor). Levine, R . (Associate General Editor). 2012. 
The Charters of Freedom “A New World is at Hand" Bill of Rights. (us.gov.). Sourced from http://www.archives.gov/exhibits/charters/bill_of_rights.html on 19. April. 2018

U.S. Constitution (Official Web Site). Retrieved on April 3, 2018, from, http://www.usconstitution.net/philosophers.html

U.S. Constitution: First Amendment: The Bill of Rights - Adopted in 1791. Retrieved on April 14, 2018, from, http://usgovinfo.about.com/od/usconstitution/a/amend1.htm

U.S. Department of The Treasury: E Pluribus Unum - An Official Website of the United States Government. Sourced from https://www.treasury.gov/about/budgetperformance/strategic-plan/Pages/dlinks.aspx on February 25, 2019.

U.S. History.Org, Historic Documents: The American Creed. Retrieved from http://www.ushistory.org/documents/creed.htm on April 3, 2018.

Yale Law School: Lillian Goldman Law Library (Official Web Site). Retrieved on September 3, 2012, from, http://avalon.law.yale.edu/18th_century/rights1.asp 